\title{
Profil Miskonsepsi Siswa SMA pada Materi Pembelajaran Suhu dan Kalor
}

\author{
Silfia Maftuhatun Ni'mah ${ }^{1}$, Sentot Kusairi ${ }^{1}$, Edi Supriana ${ }^{1}$ \\ ${ }^{1}$ Pendidikan Fisika-Universitas Negeri Malang
}

\begin{tabular}{|c|c|}
\hline INFO ARTIKEL & \multirow{6}{*}{$\begin{array}{l}\text { Abstract: This research was aimed to compare senior high school misconception with } \\
\text { different class level on heat and temperature. This study used a survey method with } \\
\text { subjects of class XI and XII as many as } 68 \text { high school students in Kediri. The instrument } \\
\text { used is in the form of two-tier items as many as } 11 \text { questions. Student responses to items } \\
\text { are categorized into three scientific knowledge, errors, and misconceptions. The results } \\
\text { of the study showed that grade XI students experienced a misconception of 54\% and class } \\
\text { XII students of } 63 \% \text {. Most students experience misconceptions in the concept of thermal } \\
\text { equilibrium. This research needs to be followed up with various efforts to overcome } \\
\text { misconceptions in physics learning. }\end{array}$} \\
\hline Riwayat Artikel: & \\
\hline Diterima: 08-04-2019 & \\
\hline Disetujui: 23-05-2019 & \\
\hline Kata kunci: & \\
\hline $\begin{array}{l}\text { misconception; } \\
\text { temperature and }\end{array}$ & \\
\hline
\end{tabular}

two-tier

miskonsepsi;

suhu dan kalor;

two-tier

\begin{abstract}
Abstrak: Penelitian ini bertujuan mengomparasikan miskonsepsi siswa SMA dengan jenjang kelas berbeda pada suhu dan kalor. Penelitian ini menggunakan metode survei dengan subjek siswa kelas XI dan kelas XII sebanyak 68 siswa SMA di wilayah Kediri. Instrumen yang digunakan berupa butir soal two-tier tentang suhu dan kalor sebanyak 11 soal. Respon siswa terhadap butir soal dikategorikan menjadi tiga, yaitu pengetahuan ilmiah, kesalahan, dan miskonsepsi. Hasil penelitian menunjukkan bahwa siswa kelas XI mengalami miskonsepsi sebesar 54\% dan siswa kelas XII sebesar 63\%. Sebagian besar siswa mengalami miskonsepsi pada konsep kesetimbangan termal. Penelitian ini perlu ditindaklanjuti dengan berbagai upaya untuk mengatasi miskonsepsi dalam pembelajaran fisika.
\end{abstract}

\author{
Alamat Korespondensi: \\ Silfia Maftuhatun Ni'mah \\ Pendidikan Fisika \\ Universitas Negeri Malang \\ Jalan Semarang 5 Malang \\ E-mail: nikmah_silfia@yahoo.com
}

Suhu dan kalor merupakan materi fisika dimana siswa banyak mengalami kesulitan atau miskonsepsi (Alwan, 2011; Sozbilir, 2003). Miskonsepsi merupakan keadaan yang mengkhawatirkan bagi pembelajaran sains terutama bidang fisika karena sifatnya yang abstrak (Kartal, Öztürk, \& Yalvaç, 2011; Alwan, 2011). Salah satu contoh miskonsepsi yang dialami siswa pada materi suhu dan kalor adalah siswa menganggap kalor merupakan suatu zat material, sedangkan para ilmuwan mendefinisikan kalor sebagai proses dinamik transmisi energi (Chiou \& Anderson, 2010). Miskonsepsi dalam pembelajaran fisika berkembang pada tingkat yang paling dasar (Kartal et al., 2011) yang berpengaruh terhadap proses pembelajaran siswa sehingga miskonsepsi menjadi masalah yang serius ketika mempelajari konsep ilmiah (Baser, 2006). Oleh karenanya miskonsepsi perlu ditangani dengan baik dan pada waktu yang tepat.

Miskonsepsi perlu ditangani dengan benar karena jika tidak maka miskonsepsi akan muncul dalam kerangka konseptual siswa bahkan sampai mereka dewasa (Baser, 2006). Miskonsepsi bisa menjadi masalah ketika mempelajari konsep ilmiah, gagasan siswa yang salah bisa membatasi proses penyaluran pembelajaran (Alwan, 2011). Pemahaman konsep ilmiah yang benar merupakan kunci untuk mempelajari konsep ilmu lainnya. Konsep dianggap sebagai ide, objek, maupun peristiwa yang membantu memahami dunia sekitar (Thompson \& Logue, 2006). Bagi pendidik sains sangat penting mengetahui pemahaman konsep siswa, hal itu berguna untuk mengembangkan kurikulum dan metode pengajaran baru (Sozbilir, 2003).

Penelitian sebelumnya mengenai identifikasi miskonsepsi siswa pada suhu dan kalor menggunakan tes pilihan ganda beralasan. Hasilnya menunjukkan bahwa sebagian besar siswa menggunakan konsepsi alternatif mereka dalam materi suhu dan kalor (Alwan, 2011). Sementara penelitian yang dilakukan oleh Kartal menggunakan tes diagnostik yang diberikan kepada mahasiswa menunjukkan bahwa mereka mengalami miskonsepsi pada materi suhu dan kalor (Kartal et al., 2011). Hasilnya mengharuskan mahasiswa untuk mengonfigurasi apa yang telah mereka pelajari sebelumnya dengan cara yang benar dan menjaganya. Penelitian sebelumnya mengenai komparasi miskonsepsi telah dilakukan oleh Rahmawati, Prayitno, \& Indrowati (2013), namun penelitian yang dilakukan bertujuan untuk mengetahui perbedaan tingkat miskonsepsi pada materi system ekskresi siswa kelas XI melalui penerapan model pembelajaran kontruktivisme tipe Novick dan pembelajaran konstruktivis-kolaboratif. 
Penelitian yang mengomparasi miskonsepsi siswa dengan jenjang kelas yang berbeda pada konsep suhu dan kalor belum pernah dilakukan. Saat ini di sekolah sudah diterapkan kurikulum 2013 yang bertipe 5M, namun belum ada penelitian mengenai dampak kurikulum 2013 bertipe 5M terhadap miskonsepsi siswa. Kurikulum 2013 yang bertipe 5M dalam pembelajaran, meliputi mengamati, menanya, mengumpulkan informasi/mencoba, mengasosiasi/mengolah informasi, dan mengomunikasikan (Kemendikbud, n.d.). Berdasarkan penejelasan tersebut, diperlukan penelitian untuk melihat apakah pembelajaran yang diterapkan di sekolah berdampak pada miskonsepsi siswa atau tidak dan juga penting untuk mengetahui perkembangan miskonsepsi siswa disetiap jenjang.

Penelitian ini bertujuan untuk mengomparasi miskonsepsi siswa dengan jenjang kelas yang berbeda pada konsep suhu dan kalor. Komparasi ini dilakukan untuk mengetahui apakah materi yang diberikan kepada siswa masih melekat dalam pemikiran mereka, serta untuk mengetahui apakah metode pembelajaran yang dilakukan memberikan pemahaman yang mendalam mengenai konsep fisika.

\section{METODE}

Penelitian ini merupakan penelitian survei yang bertujuan untuk menjelaskan aspek atau karakteristik populasi tertentu dan menguji hipotesis tentang sifat hubungan dalam suatu populasi. Inti dari penelitian survei adalah menanyai individu pada suatu topik dan kemudian menggambarkan tanggapan mereka (Jackson, 2012). Subjek penelitian yaitu siswa SMA kelas XII dan kelas XI di daerah Kediri. Siswa kelas XII berjumlah 34, dengan siswa laki-laki sebanyak 10 dan siswa perempuan sebanyak 24. Siswa kelas XI juga berjumlah 34, dengan siswa laki-laki sebanyak 12 dan siswa perempuan sebanyak 22. Rata-rata siswa berada pada ekonomi menengah ke bawah. Sebelumnya siswa belum pernah mendapatkan tes two-tier.

Instrumen yang digunakan dalam penelitian ini berupa soal two-tier sebanyak 11 soal yang diadaptasi dari soal diagnostik yang telah dikembangkan Franklin (1992) dan Kamcharean \& Wattanakasiwich (2016). Soal terdiri dari dua item, item pertama berupa respon siswa, sedangkan butir kedua berupa penjelasan ilmiah. Pengambilan data dilaksanakan dengan memberikan tes soal two-tier. Indikator yang digunakan adalah indikator ranah kognitif yang disesuaikan dengan silabus mata pelajaran fisika kelas XI K13 Revisi.

Tabel 1. Indikator Suhu dan Kalor pada Tiap Butir Soal

\begin{tabular}{clr}
\hline No. & \multicolumn{1}{c}{ Indikator } & Soal No. \\
\hline 1. & Menerapkan kesetimbangan termal dalam kehidupan sehari-hari & $1,2,6,9,10$ \\
\hline 2. & Menerapkan pengaruh kalor terhadap perubahan suhu dalam kehidupan sehari-hari & 7,8 \\
\hline 3. & Menerapkan perubahan wujud zat dalam kehidupan sehari-hari & 3 \\
\hline 4. & Menerapkan perpindahan kalor dalam kehidupan sehari-hari & 4 \\
\hline 5. & Menerapkan pengaruh perubahan suhu terhadap ukuran benda (pemuaian) dalam kehidupan sehari-hari & 5 \\
\hline 6. & Menerapkan peristiwa asas Black dalam kehidupan sehari-hari & 11 \\
\hline
\end{tabular}

Respon jawaban dari siswa dibedakan berdasarkan kategori analisis soal two-tier. Analisis kategori jawaban siswa dapat dilihat pada tabel 2 (Gurel, Körhasan, \& Gurel, 2007).

Tabel 2. Kategori Jawaban untuk Pengolahan Data 1-tier, 2-tier and 3-tier

\begin{tabular}{lll}
\hline Tier Analysis & Kategori & Jenis Respon \\
\hline 2-tier analysis & Pengetahuan ilmiah & Respon benar+penjelasan ilmiah \\
\cline { 2 - 3 } & Eror/kesalahan & Respon salah+penjelasan ilmiah \\
\cline { 2 - 3 } & Miskonsepsi & Respon benar+penjelasan tidak ilmiah \\
\cline { 2 - 2 } & & Respon salah+penjelasan tidak ilmiah \\
\hline Sumber: (Gurel et al., 2007) &
\end{tabular}

Analisis data dilakukan dengan cara menghitung persentase tiap kategori menggunakan persamaan (1) berikut ini (Amalia, Sinaga, Sari, \& Saepuzaman, 2016):

$\mathrm{P}=$ persentase dari tiap kategori

$$
P=\frac{f}{N} \times 100 \%
$$

$\mathrm{f}=$ jumlah siswa pada tiap kategori

$\mathrm{N}=$ jumlah seluruh siswa yang dijadikan subjek penelitian 
HASIL

Berdasarkan analisis data mengenai komparasi miskonsepsi siswa dengan jenjang yang berbeda, diperoleh persentase tiap kategori sebagaimana ditampilkan pada tabel 3 .

Tabel 3. Hasil Tes Two-Tier Konsep pada Materi Suhu dan Kalor

\begin{tabular}{|c|c|c|c|c|c|c|c|}
\hline \multirow{3}{*}{ No. } & \multirow{3}{*}{ Konsep } & \multicolumn{6}{|c|}{ Kategori (\%) } \\
\hline & & \multicolumn{2}{|c|}{$\begin{array}{l}\text { Pengetahuan } \\
\text { Ilmiah }\end{array}$} & \multicolumn{2}{|c|}{ Kesalahan } & \multicolumn{2}{|c|}{ Miskonsepsi } \\
\hline & & $\mathbf{X I}$ & XII & XI & XII & XI & XII \\
\hline 1. & Kesetimbangan termal dalam kehidupan sehari-hari & $5 \%$ & $9 \%$ & $9 \%$ & $1 \%$ & $84 \%$ & $90 \%$ \\
\hline 2. & Pengaruh kalor terhadap perubahan suhu dalam kehidupan sehari-hari & $19 \%$ & $63 \%$ & $7 \%$ & $3 \%$ & $71 \%$ & $34 \%$ \\
\hline 3. & Perubahan wujud zat dalam kehidupan sehari-hari & $44 \%$ & $9 \%$ & $9 \%$ & $12 \%$ & $44 \%$ & $79 \%$ \\
\hline 4. & Perpindahan kalor dalam kehidupan sehari-hari & $3 \%$ & $0 \%$ & $21 \%$ & $24 \%$ & $74 \%$ & $76 \%$ \\
\hline 5. & $\begin{array}{l}\text { Pengaruh perubahan suhu terhadap ukuran benda dalam kehidupan sehari- } \\
\text { hari }\end{array}$ & $68 \%$ & $47 \%$ & $3 \%$ & $6 \%$ & $26 \%$ & $47 \%$ \\
\hline 6. & Peristiwa asas Black dalam kehidupan sehari-hari & $53 \%$ & $47 \%$ & $21 \%$ & $3 \%$ & $24 \%$ & $50 \%$ \\
\hline & Rata-rata & $32 \%$ & $29 \%$ & $12 \%$ & $8 \%$ & $54 \%$ & $63 \%$ \\
\hline
\end{tabular}

Tabel 3 menunjukkan hasil tes siswa menggunakan soal two-tier. Berdasarkan hasil rata-rata, diketahui bahwa siswa kelas XI mengalami miskonsepsi lebih rendah dibandingkan siswa kelas XII. Siswa kelas XI mengalami miskonsepsi tinggi (persentase lebih dari 50\%) pada konsep kesetimbangan termal, pengaruh kalor terhadap perubahan suhu, dan perpindahan kalor. Siswa kelas XI tidak mengalami miskonsepsi yang tinggi (persentase dibawah 50\%) pada konsep perubahan wujud zat, pengaruh perubahan suhu terhadap perubahan ukuran benda, dan peristiwa asas Black. Kemudian siswa kelas XII mengalami miskonsepsi tinggi pada konsep kesetimbangan termal, perubahan wujud zat, dan perpindahan kalor. Siswa kelas XII tidak mengalami miskonsepsi yang tinggi pada konsep pengaruh kalor terhadpa perubahan suhu dan pengaruh perubahan suhu terhadap ukuran benda. Pada konsep peristiwa asas Black, siswa kelas XII mengalami miskonsepsi sebesar 50\%. Hasil tes two-tier dibuat grafik persentase berdasarkan kategori. Persentase kategori siswa pada konsep kesetimbangan termal dan perpindahan kalor ditampilkan pada gambar 1 dan 2.

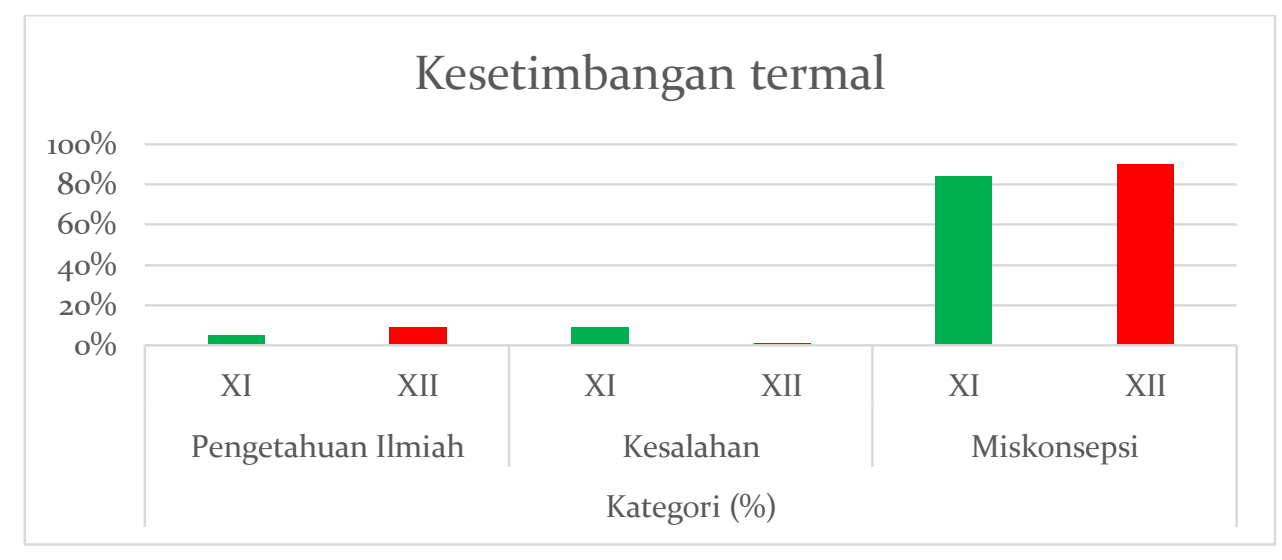

\section{Gambar 1. Grafik Persentase Kategori Siswa pada Konsep Kesetimbangan Termal}

Berdasarkan gambar 1, diketahui bahwa miskonsepsi yang dialami siswa tinggi. Miskonsepsi pada konsep kesetimbangan termal dialami siswa baik kelas XI maupun kelas XII. Siswa kelas XI mengalami miskonsepsi sebanyak 84\%, sedangkan siswa kelas XII sebanyak 90\% mengalami miskonsepsi. Sisanya mengalami kesalahan dan pengetahuan ilmiah. Berdasarkan grafik 1, siswa kelas XI mengalami miskonsepsi lebih rendah dibandingkan siswa kelas XII, begitu juga dengan kesalahan. Pada kategori pengetahuan ilmiah, siswa kelas XI lebih rendah dibandingkan siswa kelas XII. Kemudian persentase kategori siswa pada konsep perpindahan kalor dapat dilihat pada gambar 2. 


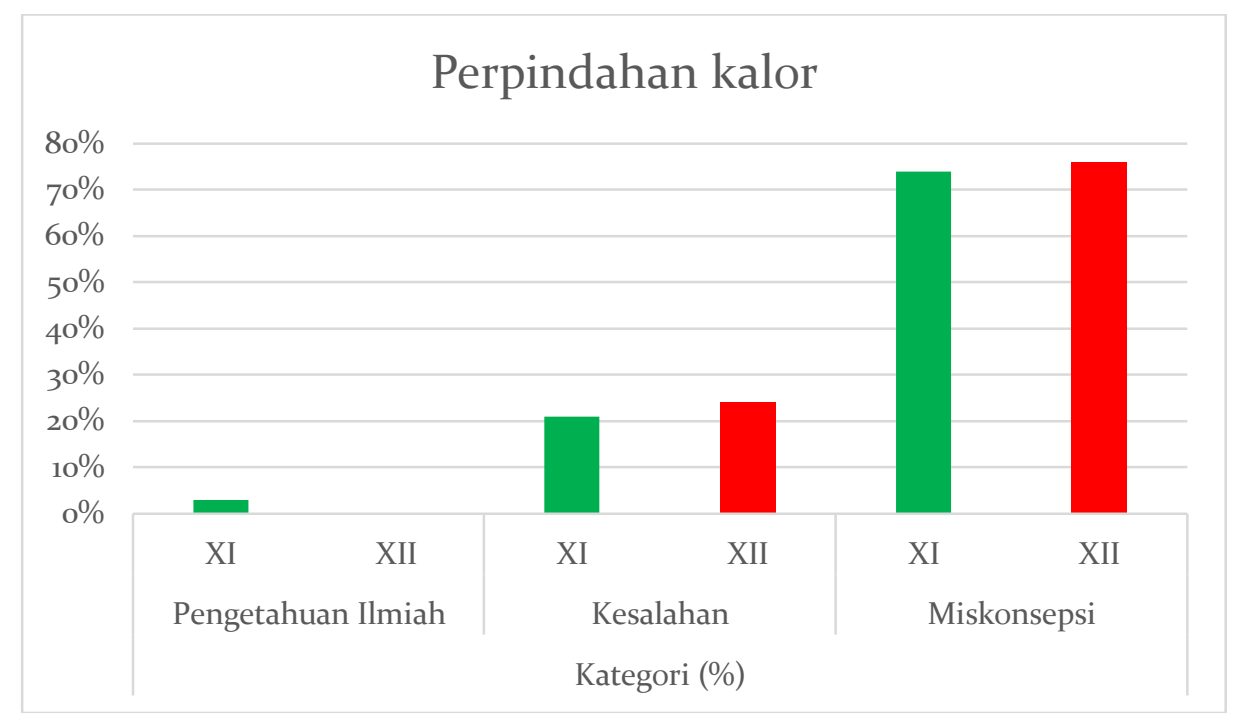

\section{Gambar 2. Grafik Persentase Kategori Siswa pada Konsep Perpindahan Kalor}

Berdasarkan gambar 2, diketahui bahwa miskonsepsi siswa pada konsep perpindahan kalor juga tinggi. Siswa kelas XI mengalami miskonsepsi sebanyak 74\%, sedangkan siswa kelas XII sebanyak 76\%. Hal ini menunjukkan bahwa siswa kelas XI mengalami miskonsepsi konsep perpindahan kalor lebih rendah dari pada kelas XII. Pada kategori kesalahan, siswa kelas XI lebih rendah daripada kelas XII. Pada kategori pengetahuan ilmiah, siswa kelas XI lebih tinggi daripada siswa kelas XII.

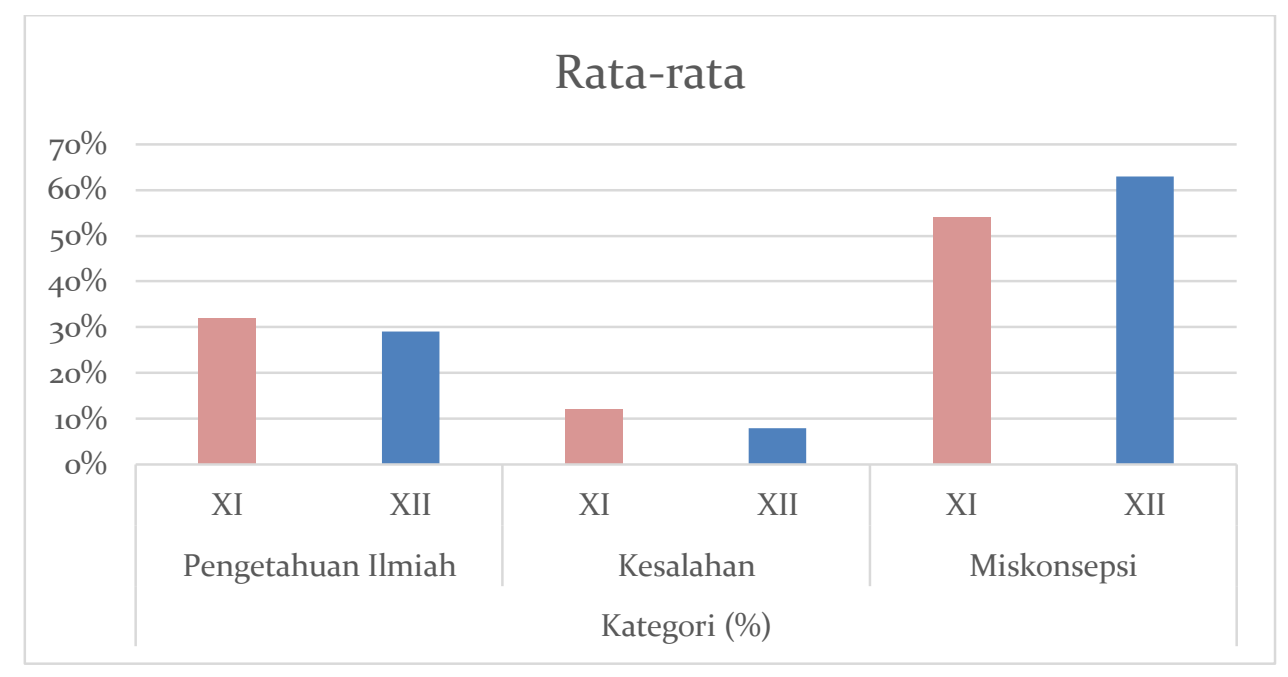

Gambar 3. Grafik Persentase Rata-Rata Kategori Two-Tier pada Siswa Kelas XI dan XII

Gambar 3 menunjukkan grafik persentase rata-rata siswa kelas XI dan XII pada konsep materi suhu dan kalor yang paling tinggi berada pada kategori miskonsepsi yaitu sebesar 54\% dan 63\%, pada kategori pengetahuan ilmiah yaitu sebesar 32\% dan 29\%, sedangkan kategori paling rendah adalah kesalahan yaitu sebesar $12 \%$ dan $8 \%$. Miskonsepsi paling tinggi dialami siswa pada konsep kesetimbangan termal baik kelas XI maupun kelas XII yaitu sebesar 54\% dan 63\%. Beberapa soal two-tier dengan materi suhu dan kalor yang digunakan pada penelitian ini adalah sebagai berikut. 
6. Terdapat tiga wadah yang sama ditempatkan dalam oven dan dipanaskan sampai $60^{\circ} \mathrm{C}\left(140^{\circ} \mathrm{F}\right)$. Masing-masing wadah berisi tepung, paku, dan air. Ketiga bahan tersebut dibiarkan di dalam oven dalam waktu yang lama sekali. Manakah dari pernyataan berikut yang paling menggambarkan suhu dari ketiga zat?

a) Tepung, paku, dan air berada pada suhu yang lebih besar dari $60^{\circ} \mathrm{C} .(\mathrm{XI}=9 \%$; XII $=9 \%)$

b) *Tepung, paku, dan air memiliki suhu yang sama yaitu $60^{\circ} \mathrm{C}$. (XI=6\%; $\left.\mathrm{XII}=0 \%\right)$

c) Suhu tepung kurang dari $60^{\circ} \mathrm{C}$, suhu paku lebih tinggi dari $60^{\circ} \mathrm{C}$, dan suhu air sama dengan $60^{\circ} \mathrm{C}$. (XI= 76\%; XII= $53 \%)$

d) Suhu tepung dan air berada pada $60^{\circ} \mathrm{C}$, namun suhu paku lebih tinggi dari $60^{\circ} \mathrm{C}$. (XI= $9 \%$; XII $\left.=24 \%\right)$

e) Suhu tepung dan air berada di bawah $60^{\circ} \mathrm{C}$, sedangkan suhu paku di atas $60^{\circ} \mathrm{C}$. $(\mathrm{XI}=0 \%$; $\mathrm{XII}=15 \%)$

Alasan:

1) Logam menyerap panas dan memiliki kecenderungan menarik panas. $(\mathrm{XI}=18 \% ; \mathrm{XII}=26 \%)$

2) Logam kehilangan panas dengan cepat, membuatnya terasa lebih dingin. $(\mathrm{XI}=0 \% ; \mathrm{XII}=6 \%)$

3) Paku besi menyerap lebih banyak panas karena paku merupakan logam; air menjadi yang terpanas berikutnya karena air mendidih, dan tepung akan menjadi yang paling dingin karena tidak ada apa-apanya. (XI=74\%; XII=62\%)

4) *Energi kalor keluar untuk benda-benda yang bersentuhan dengan lingkungannya sehingga suhunya sama. (XI= 3\%; $\mathrm{XII}=0 \%$ )

5) Selama benda-benda berada di oven, oven meningkatkan suhu sehingga suhu benda-benda naik sampai di atas oven. (XI= $6 \% ; \mathrm{XII}=6 \%$ )

7. Jika 100 gram es pada $0^{\circ} \mathrm{C}$ dan 100 gram air pada $0^{\circ} \mathrm{C}$ dimasukkan ke dalam freezer yang memiliki suhu di bawah $0^{\circ} \mathrm{C}$. Setelah menunggu hingga suhu es dan air sama dengan suhu freezer, manakah yang akan kehilangan jumlah kalor terbanyak?

a) 100 gram es $(\mathrm{XI}=15 \% ; \mathrm{XII}=6 \%)$

b) $* 100$ gram air $(\mathrm{XI}=59 \% ; \mathrm{XII}=88 \%)$

c) Keduanya kehilangan jumlah kalor yang sama $(\mathrm{XI}=12 \% ; \mathrm{XII}=6 \%)$

d) Tidak ada jawaban (XI= $15 \% ; \mathrm{XII}=0 \%)$

Alasan:

1) *Air harus berubah menjadi es sebelum turun suhunya (XI= 47\%; XII $=68 \%)$

2) Keduanya (air dan es) memiliki suhu awal yang sama $\left(0^{\circ} \mathrm{C}\right)(\mathrm{XI}=21 \%$; XII $=12 \%)$

3) Es tidak mengandung kalor $(\mathrm{XI}=18 \%$; $\mathrm{XII}=21 \%)$

4) Air tidak dapat mencapai suhu $0{ }^{\circ} \mathrm{C}(\mathrm{XI}=15 \%$; $\mathrm{XII}=0 \%)$

10. Terdapat tiga buah mangkuk dengan ukuran yang sama diletakkan di atas meja dapur selama satu malam. Ketiga mangkuk terbuat dari kayu, logam, dan plastik. Suhu ruang adalah $75^{\circ} \mathrm{F}$ sepanjang waktu. Bagaimana perbandingan suhu ketiga mangkuk?

a) Mangkuk logam memiliki suhu terendah; mangkuk plastik tertinggi berikutnya; dan mangkuk kayu memiliki suhu paling tinggi. $(\mathrm{XI}=3 \% ; \mathrm{XII}=44 \%)$

b) *Suhu ketiga mangkuk sama dengan suhu ruang, $75^{\circ} \mathrm{F} .(\mathrm{XI}=0 \% ; \mathrm{XII}=6 \%)$

c) Mangkuk plastik memiliki suhu terendah; mangkuk kayu tertinggi berikutnya; dan mangkuk logam memiliki suhu paling tinggi. $(\mathrm{XI}=50 \% ; \mathrm{XII}=29 \%)$

d) Mangkuk kayu dan mangkuk plastik memiliki suhu sama, sedangkan mangkuk logam memiliki suhu yang paling tinggi. (XI= $35 \% ; \mathrm{XII}=21 \%$ )

e) Suhu ketiga mangkuk lebih rendah dari pada suhu ruang. (XI= $12 \%$; XII= $0 \%)$

Alasan:

1) Logam menyerap panas dan memiliki kecenderungan untuk menarik panas. (XI=62\%; XII $=32 \%$ )

2) Logam kehilangan panas secara cepat, sehingga membuatnya terasa lebih dingin. $(\mathrm{XI}=18 \% ; \mathrm{XII}=47 \%)$

3) Plastik dan kayu adalah insulator yang baik, sehingga membuatnya terasa lebih hangat. (XI=9\%; XII= 12\%)

4) *Kalor akan lepas untuk benda yang memiliki suhu lebih rendah, sehingga masing-masing mangkuk memiliki suhu yang sama. $(\mathrm{XI}=6 \% ; \mathrm{XII}=6 \%)$

5) Benda-benda seperti kayu, logam, dan plastik merupakan benda mati dan tidak dapat menahan panas, sehingga benda tersebut lebih dingin daripada lingkungannya. (XI=6\%; $\mathrm{XII}=3 \%)$

Soal no.6 merupakan soal konsep kesetimbangan termal. Hasil analisisnya, siswa kelas XI dan XII menganggap bahwa benda-benda dengan bahan berbeda jika diletakkan dalam oven maka memiliki suhu yang berbeda. Menurut mereka paku memiliki suhu yang tertinggi karena paku terbuat dari logam sehingga menyerap lebih banyak panas. Kemudian air memiliki suhu dibawah paku karena air dapat mendidih. Dan tepung memiliki suhu paling rendah. Berdasarkan jawaban siswa tersebut, dapat diketahui bahwa secara keseluruhan siswa membawa apa yang mereka alami dalam kehidupan sehari-hari ke dalam pemikiran mereka. 
Hasil analisis jawaban siswa pada soal no.7 dengan konsep pengaruh kalor terhadap perubahan suhu benda, diketahui baik siswa kelas XI maupun kelas XII sudah mengetahui bahwa air harus berubah wujud menjadi es sebelum suhunya turun. Air kehilangan kalor lebih banyak dari padan es meskipun massa dan suhunya yang sama. Hal ini menunjuukan bahwa siswa kelas XI dan XII memiliki pengetahuan ilmiah pada konsep pengaruh kalor terhadap perubahan suhu benda.

Pada analisis jawaban soal no.10 dengan konsep kesetimbangan termal, diketahui siswa kelas XI dan XII memiliki pemikiran yang sama dengan soal no.7 bahwa benda-benda dengan bahan yang berbeda jika diletakkan dalam suatu ruang maka memiliki suhu yang berbeda. Siswa kelas XI menganggap logam memiliki suhu tertinggi, kemudian kayu dan plastik karena logam menyerap panas, sementara siswa kelas XII menganggap kayu memiliki suhu tertinggi, kemudian plastik dan logam karena logam kehilangan panas secara cepat. Hal ini mengindikasikan bahwa secara keseluruhan siswa membawa apa yang dialami dalam kehidupan sehari-hari ke dalam pemikiran mereka.

\section{PEMBAHASAN}

Rata-rata siswa kelas XI dan XII masih mengalami miskonsepsi pada materi suhu dan kalor. Miskonsepsi yang paling tinggi terjadi pada konsep kesetimbangan termal. Berdasarkan analisis jawaban siswa diketahui bahwa miskonsepsi yang terjadi dikarenakan mereka membawa apa yang dialami pada kehidupan sehari-hari ke dalam pemikiran mereka, sehingga apa yang mereka pahami tidak sesuai dengan pengetahuan ilmiah. Berdasarkan penelitian Lestari \& Linuwih (2014), faktor yang menyebabkan siswa mengalami konsepsi alternatif dan konsepsi parallel adalah pengetahuan awal atau anggapan dasar dalam kehidupan sehari-hari siswa (Alwan, 2011; Baser, 2006). Faktor yang lain adalah penguasaan materi fisika yang lemah, hal ini disebabkan karena siswa mendapatkan pembelajaran dengan metode ceramah kemudian melakukan latihan soal sehingga siswa hanya belajar pada pola permukaan (surface pattern matching learning). Faktor lainnya yaitu faktor pengetahuan sebagai struktur teoritis dimana siswa langsung menjawab dengan teori dan anggapan awal yang salah, serta faktor apresiasi konseptual dimana siswa menjawab secara praktis dan tidak meninjau jawaban mereka lebih dalam (Lestari \& Linuwih, 2014).

Penelitian juga menemukan bahwa siswa kelas XII mengalami miskonsepsi lebih tinggi dari pada siswa kelas XI. Perbedaan jumlah miskonsepsi tersebut dapat terjadi mengingat siswa kelas XI baru saja menerima pelajaran suhu dan kalor, sementara siswa kelas XII sudah menerima pelajaran suhu dan kalor beberapa waktu lalu. Guru yang mengajar dan model pembelajaran yang digunakan berbeda, sehingga jumlah siswa yang mengalami miskonsepsi juga berbeda. Rata-rata siswa kelas XII mengalami miskonsepsi lebih tinggi, namun pada konsep kesetimbangan termal dan pengaruh kalor terhadap perubahan suhu siswa kelas XII mengalami kategori pengetahuan ilmiah lebih tinggi dibandingkan siswa kelas XI. Rata-rata siswa kelas XI juga mengalami kategori kesalahan (error) lebih besar dibandingkan siswa kelas XII.

Miskonsepsi yang tinggi pada kelas XII apabila dikomparasikan dengan penelitian yang dilakukan oleh Lestari \& Linuwih (2014) adalah sama, dimana siswa kelas XII mengalami konsepsi alternatif lebih tinggi dibanding siswa kelas X. Penelitian Lestari \& Linuwih (2014) menunjukkan bahwa siswa kelas XII mengalami konsepsi ilmiah lebih tinggi dari pada siswa kelas X, sedangkan konsepsi parallel siswa kelas XII lebih rendah dari pada siswa kelas X. Konsepsi ilmiah didapatkan dari jawaban benar, sedangkan konsepsi alternatif dan parallel didapatkan dari jawaban salah. Konsepsi paralel merupakan perpaduan antara konsepsi alternatif dan konsepsi ilmiah serta perpaduan antara dua konsepsi alternatif.

Hasil penelitian ini berbeda dengan penelitian yang sudah ada. Penelitian yang dilakukan oleh Wulandari, Prihandono, \& Maryani, (2018) menunjukkan bahwa siswa kelas XI di Jember mengalami miskonsepsi sebesar 44\%. Miskonsepsi tertinggi berada pada butir soal yang mengungkapkan konsep hubungan antara suhu dan kalor yaitu sebesar 65\%. Penelitian yang dilakukan oleh Amalia et al., (2016) menunjukkan bahwa siswa kelas XI di kota Bandung mengalami miskonsepsi sebesar 43\%. Miskonsepsi tertinggi berada pada butir soal yang mengungkapkan konsep kalor. Penelitian lain mengenai miskonsepsi suhu dan kalor yang dilakukan oleh Wahidah S., Kusairi, \& Zulaikah (2016) menggunakan three-tier test menunjukkan bahwa siswa masuk kategori menguasai konsep sebanyak 47\%, siswa mengalami miskonsepsi sebanyak 38\%, siswa menebak sebanyak 5\%, dan siswa tidak tahu konsep sebanyak 10\% dari total 136 siswa (Wahidah, et al., 2016).

Berdasarkan penelitian yang dilakukan, peneliti merekomendasikan supaya guru memperdalam materi suhu dan kalor pada konsep kesetimbangan termal, perubahan wujud zat, perpindahan kalor, dan asas Black karena pada konsep tersebut siswa mengalami miskonsepsi lebih dari 50\%. Berdasarkan penelitian yang lain, salah satu penyebab rendahnya hasil belajar fisika adalah proses belajar yang tidak melibatkan keaktifan siswa dimana siswa sebagai pendengar dan guru lebih dominan (teacher centered) (Ma'rifah, Parno, \& Mufti, 2016). Salah satu metode belajar yang disarankan adalah modeling instruction, karena metode ini dikembangkan untuk membantu siswa memiliki pemahaman konsep-konsep yang mendalam (Arseneault, 2014). Metode ini dikembangkan untuk reformasi pendidikan sains di sekolah menengah (Barlow, Frick, Barker, \& Phelps, 2014). Didalam pembelajaran ini, siswa memiliki pemahaman yang mendalam tentang konsep fisika karena siswa melakukan eksperimen, menganalisis data, dan menemukan hubungan sendiri (Arseneault, 2014). Model ini terbukti membantu siswa kelas XI untuk mengatasi miskonsepsi mereka pada materi suhu dan kalor sehingga miskonsepsi mereka lebih rendah dibandingkan siswa kelas XII. Melalui pembelajaran tersebut, diharapkan siswa bisa memiliki konsep fisika yang mendalam dan melekat sampai mereka dewasa, serta diharapkan tidak mengalami miskonsepsi lagi. 


\section{SIMPULAN}

Penelitian menemukan bahwa miskonsepsi yang dialami siswa tinggi. Siswa mengalami miskonsepsi pada konsep suhu dan kalor, meskipun mereka sudah mempelajari materi tersebut di SMP. Miskonsepsi yang dialami siswa kelas XI lebih rendah dibandingkan siswa kelas XII. Hal ini menunjukkan bahwa pembelajaran yang diberikan belum mampu membuat siswa mengingatnya sampai ke jenjang kelas yang lebih tinggi.

Penelitian lebih lanjut dapat dilakukan untuk mengeksplorasi penyebab siswa mengalami miskonsepsi pada suhu dan kalor. Peneliti memberikan saran untuk menerapkan berbagai pendekatan dan metode pembelajaran yang dapat membangun pemahaman yang mendalam dan kuat pada konsep-konsep ilmiah.

\section{DAFTAR RUJUKAN}

Alwan, A. A. (2011). Misconception of heat and temperature Among physics students. Procedia - Social and Behavioral Sciences, 12, 600-614. https://doi.org/10.1016/j.sbspro.2011.02.074

Amalia, R., Sinaga, P., Sari, I. M., \& Saepuzaman, D. (2016). Identifikasi Miskonsepsi Siswa SMA di Kota Bandung pada Konsep Suhu dan Kalor. Pros. Semnas Pend. IPA Pascasarjana UM, 1.

Arseneault, M. (2014). The Effects of Modeling Instruction in a High School Physics Classroom. LSU Master's Theses. Retrieved from https://digitalcommons.lsu.edu/gradschool_theses/4257

Barlow, A. T., Frick, T. M., Barker, H. L., \& Phelps, A. J. (2014). Modeling Instruction: The Impact of Professional Development on Instructional Practices. Science Educator, 23(1), 14-26.

Baser, M. (2006). Effect of Conceptual Change Oriented Instruction on Students' Understanding of Heat and Temperature Concepts. Online Submission, 4(1), 64-79.

Chiou, G. L., \& Anderson, O. R. (2010). A Study of Undergraduate Physics Students' Understanding of Heat Conduction Based on Mental Model Theory and an Ontology-Process Analysis. Science Education, 94(5), 825-854. https://doi.org/10.1002/sce.20385

Franklin, B. J. (1992). The Development, Validation, and Application of a Two-Tier Diagnostic Instrument to Detect Misconceptions in the Areas of Force, Heat, Light and Electricity. LSU Digital Commons, 346.

Gurel, D. K., Körhasan, N. D., \& Gurel, D. K. (2007). Identification of Pre-Service Physics Teachers\&\#39; Misconceptions on Gravity Concept: A Study with a 3-Tier Misconception Test. AIP Conference Proceedings. Retrieved from https://www.academia.edu/609890/Identification_of_Pre_Service_Physics_Teachers_Misconceptions_on_Gravity_Co ncept_A_Study_with_a_3_Tier_Misconception_Test

Jackson, S. L. (2012). Research Methods and Statistics: A Critical Thinking Approach. Cengage Learning.

Kamcharean, C., \& Wattanakasiwich, P. (2016). Development and Implication of a Two-tier Thermodynamic Diagnostic Test to Survey Students' Understanding in Thermal Physics. International Journal of Innovation in Science and Mathematics Education. Retrieved from file:///C:/Users/admin/Downloads/8710-28352-3-PB.pdf

Kartal, T., Öztürk, N., \& Yalvaç, H. G. (2011). Misconceptions of Science Teacher Candidates about Heat and Temperature. Procedia - Social and Behavioral Sciences, 15, 2758-2763. https://doi.org/10.1016/j.sbspro.2011.04.184

Kemendikbud. (n.d.). Dokumen Kurikulum 2013. http://yogyakarta.kemenag.go.id/file/file/dikmad/ldue1388737894.pdf

Lestari, P. P., \& Linuwih, S. (2014). Analisis Konsepsi dan Perubahan Konseptual Suhu dan Kalor pada Siswa SMA Kelas Unggulan. Unnes Physics Education Journal, 3(2), 63-67.

Ma'rifah, E., Parno., \& Mufti, N. (2016). Identifikasi Kesulitan Siswa pada Materi Suhu dan Kalor. Jurnal Pembelajaran Fisika, 4(5), 124-133.

Rahmawati, Y., Prayitno, B. A., \& Indrowati, M. (2013). Studi Komparasi Tingkat Miskonsepsi Siswa pada Pembelajaran Biologi melalui Model Pembelajaran Konstruktivisme Tipe Novick dan Konstruktivis-kolaboratif - Neliti. Seminar Nasional X Pendidikan Biologi FKIP UNS 2013, 7, 11-26.

Sozbilir, M. (2003). A Review of Selected Literature on Students' Misconceptions of Heat and Temperature. Boğaziçi University Journal of Education, 20.

Thompson, F., \& Logue, S. (2006). An Exploration of Common Student Misconceptions in Science. International Education Journal, 7(4), 553-559.

Wahidah S., S. N., Kusairi, S., \& Zulaikah, S. (2016). Diagnosis Miskonsepsi Siswa SMA di Kota Malang pada Konsep Suhu dan Kalor menggunakan Three Tier Test. Jurnal Pendidikan Fisika dan Teknologi, 2(3), 95-105.

Wulandari, T. A., Prihandono, T., \& Maryani, M. (2018). Analisis Miskonsepsi Siswa pada Materi Suhu dan Kalor di Kelas XI SMA Jember. FKIP E-Proceeding, 3(1), 135-139. 